\title{
Institutional Analysis of Watershed Manangement in Batam Island
}

\author{
Syahrul Donie \\ Balai Penelitian Teknologi Pengelolaan DAS \\ Jl. A.Yani-Pabelan Kartasura-Surakarta \\ Corresponding Author (email: syahruldonie@gmail.com)
}

\begin{abstract}
This study aimed to look at the institutional condition of the current watershed management and institutional models (management authority) which were relevant to Batam Island in the future. The data collection was conducted by interview techniques and was validated through focus group discussions. The data were described and analyzed with SCP (structure, conduct, performance) method for relevant stakeholders' data, legislation, and with KIPA (quadrant interpretative performance analysis) method for data of interest and power of stakeholders. The results showed that the watershed management institutional in Batam Island was still overlapping. According to the regulations, the Management Board (BP) of Batam Island was given the authority to manage and to use land and water; on the other hand the Local Government (Mayor) was facilitated by BPDAS KEPRI (Watershed Management Institute of Riau Islands) to also arrange an integrated watershed management. The results of discussions showed that BP Batam was an institute of having interest and power as well as key position in achieving successful watershed management. Based on this study, it was suggested that BP Batam should be given authority in watershed management in Batam Island, which keeps referring to the norms, standards, procedures, and indicators set by the central government.
\end{abstract}

Keywords: Batam Island, watershed management, institutional model

\begin{abstract}
Abstrak
Kajian ini bertujuan untuk melihat kondisi kelembagaan pengelolaan DAS saat ini dan model kelembagaan (kewenangan kepengurusan) yang relevan ke depan di Pulau Batam. Pengambilan data dilakukan dengan teknik wawancara dan divalidasi melalui diskusi kelompok terarah. Data dideskripsikan dan dianalisis dengan metoda SCP (structure, conduct, performance) untuk data parapihak terkait, peraturan perundangan,dan dengan metoda KIPA (kuadrant interpretative performance analysis) untuk data ketertarikan dan kekuatan parapihak. Hasil penelitian menunjukkan bahwa kelembagaan pengelolaan DAS di Pulau Batam masih tumpang tindih. Sesuai peraturan, Badan Pengelola (BP) Batam diberi kewenangan untuk mengelola dan memanfaatkan tanah dan air, disisi lain pihak Pemerintah Daerah (Wali Kota) yang difasilitasi oleh BPDAS Kepri juga menyusun Pengelolaan DAS terpadu. Hasil diskusi menunjukkan bahwa BP Batam merupakan pihak yang memiliki kepentingan dan memiliki kekuatan serta pihak kunci tercapainya keberhasilan pengelolaan DAS. Dari hasil kajian tersebut disarankan bahwa BP Batam perlu diberi kewenangan dalam pengelolaan DAS di Pulau Batam dengan tetap mengacu kepada norma, standar, prosedur dan indikator yang ditetapkan oleh pusat.
\end{abstract}

Kata Kunci: Pulau Batam, pengelolaan DAS, model kelembagaan

\section{Introduction}

Batam Island in the region of Batam, Riau Islands Province, has an area of 41,500 ha $(\mathrm{BP}$ Batam, 2015) or 41,514.08 ha (BPKH, 2015), is one of islands that is categorized as small island $\left(<2000 \mathrm{~km}^{2}\right)$ in Indonesia (Cahyadi, 2013). Based on the Presidential Decree No. 41 of 1973, Batam Island was developed as an Industrial Area, and through the Presidential Regulation No. 87 of 2011, it was set to be one of the National Strategic Areas.
Since the release of the Presidential Decree No. 41 of 1973, Batam Island developed rapidly either from economy, population or human activity sectors. The population in 1997, which was recorded to be, 254,302 people (BPS, 2013) increased to $1,031,121$ inhabitants in 2015 (Batam Indonesia, 2015). The economic growth in 2014 reached $7.99 \%$ and GDPR reached IDR 108.72 Trillion, with economic structure focused on industrial sector (Batam Indonesia, 2015). However, rapid economic 
growth was also followed by environmental impacts among others were conversion of land use for housing, offices, factories, roads, and others. The forest cover area in 1990, whih was $6,660.44$ ha, decreased to $3,705.60$ ha in 2014; on the contrary, residential land increased from $1,1624.88$ ha in 1990 to $16,424.95$ ha in 2014 (BPKH, 2015).

The percentage of each land cover in Batam Island in 2014 (Pramono, et al. 2015) was presented in Figure 1 and Figure 2. The largest land cover was settlement ( $>38 \%$ ), followed by mangrove forest, secondary forest and shrubs. Similarly, the area of open land that exceeds dry land forest area. The high use of land for settlements was one of consequence from development of the island as a result of economic growth. Trimeko (2014) said that population growth and economic activity will have an impact on land-use change, either from forests to agricultural land, or from agricultural land to residential, industrial and urban and finally gave impact water system. This is further worsened by a decline in area and quality of forest cover (Photo $2 \mathrm{c}$ ), so that the condition of water system in the island of Batam was dry in the dry season and floods in rainy period (Photo $2 a$ ).

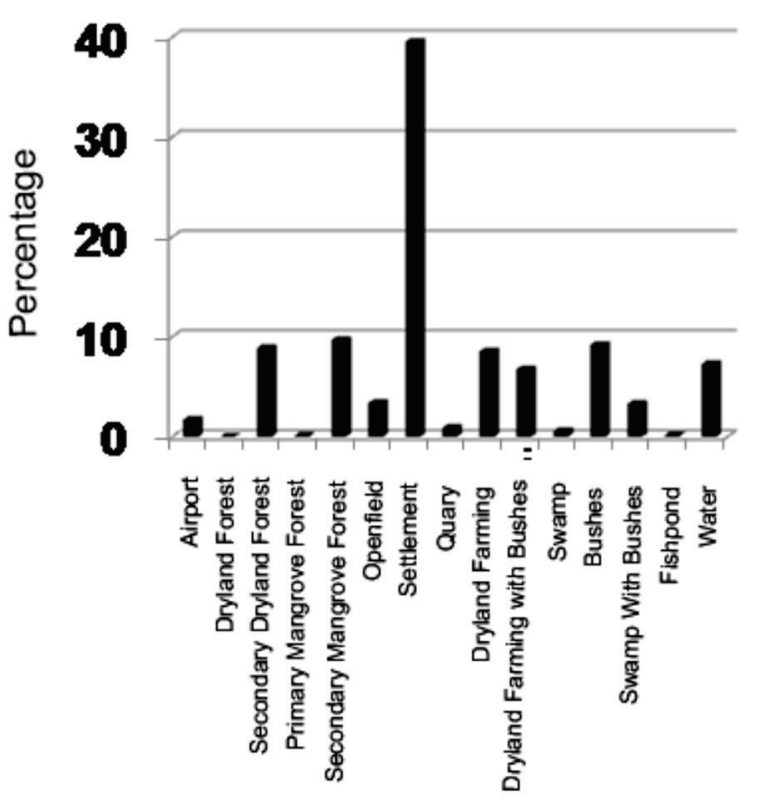

Figure 1. Percentage of land cover in Batam island (Pramono et al., 2015)

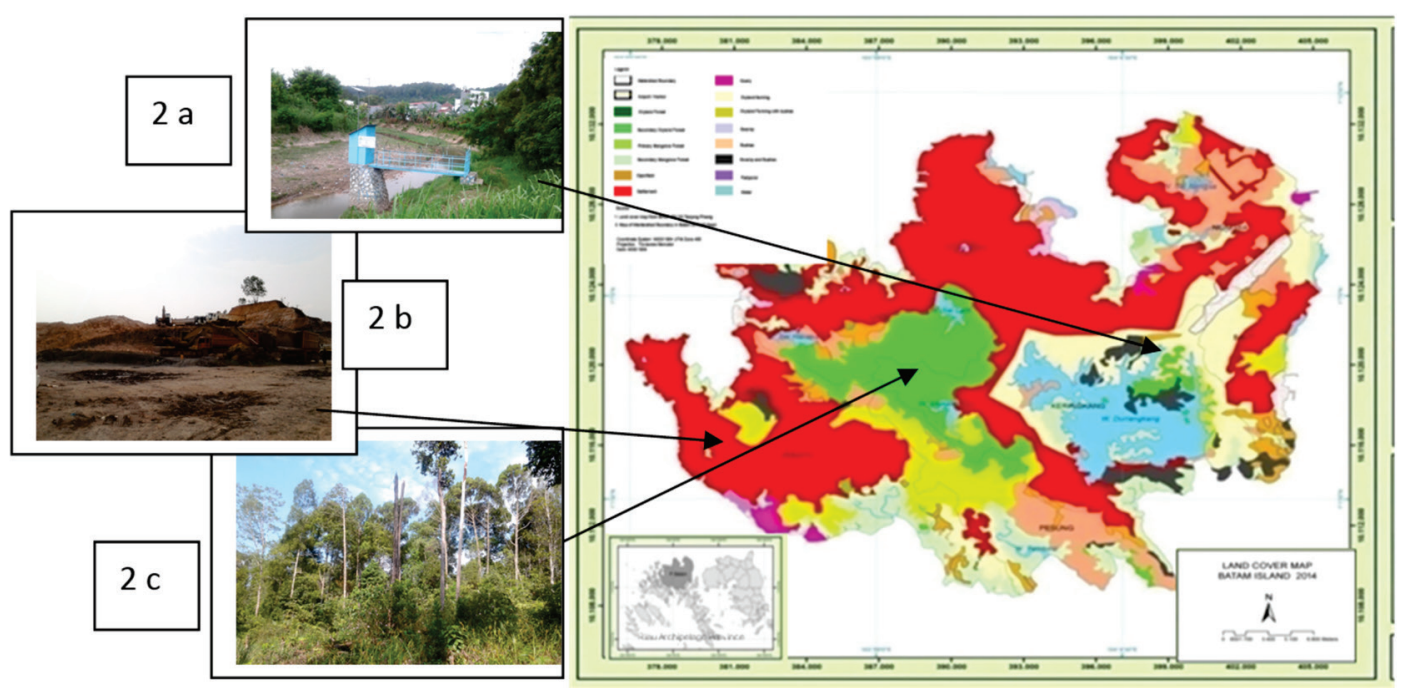

Figure 2. Land cover on Batam Island in 2014 (BPKH, 2015) 
Suripin (2002) in Utaya (2008) stated that land use change can threaten the existence of groundwater because changes in land use, in addition to land cover change, can also alter the biophysical properties of land as a result of the changes of land use. Soil biophysical changes will result in a decrease of water (rain) absorption capacity into the ground. Anna et al., (2010) in their research conducted in Sukoharjo proved that land conversion of open land (paddy / moor/ forest / garden) into smaller plots (residential / buildings / public facilities) resulted in an increased of the decreasing flow coefficient and capacity of water into soil.

Related to Batam Island, Medrial Zain et al., (2006) described that the area of Batam, which had a high ability to conserve water (zone 5), was only $13.36 \%$ and the rest belonged to zone 1-2 (less capable). As shown in Photo $2 \mathrm{~b}$, the soil layer which was expected to function for absorbing and storing rainwater, was dig up and disposed to be built housing or industry. Under such conditions, Sianipar (2011) estimated that Batam would suffer from shortage of water supply in 2015.

Pramuka Island that was utilized for tourism currently suffer from water shortages because it was not managed properly (Cahyadi, 2013). In order to prevent the similar thing from occurring in Batam Island, the watershed management in the Island should be managed properly. In order to ensure the watershed management to function properly, a strong institutional management in accordance with its functions was needed.

Johnson (1999) said that an institutional management was an important element in running the development, in addition to human resources element, natural resources, and technology. Those four elements were required and to mutually support each other in achieving the stated goal. There were two important things that were needed to be seen in institutional study; the first was institutional aspect and second was organizational aspect related to both with institutions and stakeholders (Mitchell, 1968; Uphoff, 1986). From the institutional aspect there would be known as norms (regulations) which were used; while from institution aspect there would be relevant stakeholders and strengths as well as interests from each institution.

Related to the institutional aspect of watershed management of Batam Island, it was inseparable from the history of formation and development of the existing institutions, among others Batam Management Board, Government of Batam Municipality, Riau Islands Province and the Central Government (Ministry of Environment and Forestry or the Ministry of Public Works). Based on the Presidential Decree No. 41 of 1973 and strengthened by the Government Regulation No. 46 of 2007, the Management Board (BP) of Batam was given the authority to manage land and water in Batam Island. Based on the Government Regulation No. 37 of 2012, the authority of watershed at level of one district/ city was Head of District/Mayor. Also, if associated with the Presidential Decree No. 12 of 2012 where the river on the island of Batam belonged to strategic river area, its authority was in the Central Government (the Minister). This overlap was feared that it would give impact to sustainability of the watershed in general or sustainability of natural resources, especially on that island. This study aimed to look at the condition of the current watershed management institutional aspect and institutional models that were relevant in the future in Batam Island, especially from its authority aspects.

\section{Research Method}

The study was carried out in JanuaryDecember 2015 in Batam Island, Riau Islands. The data collection were conducted by interview techniques with a number of community respondents and related stakeholders (Table 1), among others the characteristics of data, perceptions, interests and power of stakeholders as well as legislation related to the watershed management in 
Batam Island. The results of interviews were described and validated through focus group discussions. SCP analyses method (structure, conduct, performance) was used to see the characteristics of stakeholders, perceptions and legislation, while determining the key stakeholders, a quadrant analysis adopted from KIPA method (quadrant interpretative performance analysis) were used.

Table 1. Respondents and Stakeholders of FGD (Focus Group Discussion) Participants in Batam Island.

\begin{tabular}{|c|c|c|}
\hline No. & Stakeholders of & FGD Participants \\
\hline 1 & $\begin{array}{l}\text { Head of Bappedalda (Local Environment } \\
\text { Impact Controlling Agency) of Batam city }\end{array}$ & Head Division of Setdako Batam \\
\hline 2 & Deputy of Development of BP Batam & Head Division of Program KP2K Batam city \\
\hline 3 & Head of KP2K Batam city & Deputy of PT Adhy Tirta Batam (ATB) \\
\hline 4 & Head of Public Work of Batam city & $\begin{array}{l}\text { Head of Farmers Group (Sumber Makmur } \\
\text { Tembesi) }\end{array}$ \\
\hline 5 & $\begin{array}{l}\text { Head of Physic and Infrastructure Bappeda } \\
\text { (Local Planning \& Development Agency) of } \\
\text { Batam city }\end{array}$ & Section of BKPH Riau Islands area \\
\hline 6 & $\begin{array}{l}\text { Head of Forestry Division KP2K Service of } \\
\text { Batam city }\end{array}$ & $\begin{array}{l}\text { Head of Watershed management Forum of Riau } \\
\text { Islands }\end{array}$ \\
\hline 7 & $\begin{array}{l}\text { Head of Agriculture Division KP2K Service } \\
\text { of Batam city }\end{array}$ & NGOs \\
\hline 8 & $\begin{array}{l}\text { Section of PSDA Center, Kepri (Riau Islands) } \\
\text { area, Batam area }\end{array}$ & $\begin{array}{l}\text { Community (Community leaders, managers and } \\
\text { users of land in the Batam watershed) }\end{array}$ \\
\hline 9 & Head of BPDAS Riau Islands & Section of BPN \\
\hline 10. & Section of BKSDA Riau Islands area & Researchers of BPTKPDAS Solo \\
\hline
\end{tabular}

Source: FGD November 2015

\section{Results And Discussion}

Analysis of Regulations and Laws Related to Watershed Institution

From regulations and laws perspective, watershed management authority in Batam Island was still overlapping. They were shown by some rules and regulations related to watershed management in Batam Island (Table 2). Based on the Government Regulation No. 37 of 2012 on Watershed Management, watershed in Batam Island was under the authority of the Mayor because it was located in one city, while based on the Presidential Decree No. 12 of 2012 related to basin, the river basin in Batam Island belonged to the strategic river basin whose authority laid in the central government; even though in the hierarchal structure of watershed management (PP 37, 2012), the river basin of Batam Island was located within one district/city.

On the other hand, the Institute of Watershed Management or BPDAS as Technical Management Unit (UPT) of Ministry of Environment and Forestry had facilitated the establishment of Integrated Watershed Management Plan Team of Duri Angkang Watershed in Batam Island as a follow up of the Ministry of Forestry Decree No. 328 of 2009 on the Determination of Watershed priority, in which one them was Duri Angkang watershed in Batam Island. The Team had completed their work and produced a Book 
of Integrated Watershed Management Plan Duri Angkang signed by the Mayor of Batam (BPDAS of Kepri, 2011). In accordance with the Regulation No. 37 of 2012, things that had been done by BPDAS were in accordance with the regulations as watershed management plan (Ministry of Forestry Regulation No. 39 of 2009). However, when referring to the Presidential Decree No. 12 of 2012, things that had been done by Batam Mayor were less appropriate because these were the authority of the Central Government.

Table 2. Some Regulations related to Watershed Management Authority in Riau Islands

\begin{tabular}{|c|c|c|c|c|}
\hline Regulation & $\begin{array}{l}\text { Characteristics of } \\
\text { Watershed }\end{array}$ & Authority & Island & $\begin{array}{l}\text { Example of } \\
\text { watershed }\end{array}$ \\
\hline \multirow[t]{2}{*}{ PP 37/ 2012} & One district & $\begin{array}{l}\text { Head of District/ } \\
\text { Mayor }\end{array}$ & $\begin{array}{l}\text { Batam, Bintan } \\
\text { and other islands }\end{array}$ & $\begin{array}{l}\text { Duriangkang, } \\
\text { Tembesi (Batam) } \\
\text { Jago (Bintan) }\end{array}$ \\
\hline & Inter district & Governor & Bintan & Pulai, Jang \\
\hline \multirow[t]{3}{*}{ Keppres $12 / 2012$} & One district & $\begin{array}{l}\text { Head of District/ } \\
\text { Mayor }\end{array}$ & $\begin{array}{l}\text { Batam, Bintan } \\
\text { and } \\
\text { Other islands }\end{array}$ & $\begin{array}{l}\text { Duriangkang, } \\
\text { Tembesi (Batam) } \\
\text { Jago (Bintan) }\end{array}$ \\
\hline & Inter district & Governor & Bintan & Pulai, Jang \\
\hline & National Strategic & Minister & Batam, Bintan & $\begin{array}{l}\text { Existing river in that } \\
\text { island }\end{array}$ \\
\hline \multirow[t]{2}{*}{$\begin{array}{l}\text { RPDAST by } \\
\text { BPDAS }\end{array}$} & One district/city & Mayor & Batam & Duriangkang \\
\hline & Inter district & Governor & Bintan & Jang \\
\hline $\begin{array}{l}\text { KepMenDagri } \\
\text { No 43/1977 Soil } \\
\text { management right } \\
\text { in Batam Island) }\end{array}$ & One island & $\begin{array}{l}\text { Management } \\
\text { Agency (BP) } \\
\text { Batam }\end{array}$ & Batam & $\begin{array}{l}\text { Right of uses and } \\
\text { management of land }\end{array}$ \\
\hline UU No 23/ 2014 & $\begin{array}{l}\text { Inter district and one } \\
\text { district }\end{array}$ & Governor & All Kepri & $\begin{array}{l}\text { All watershed in } \\
\text { Kepri }\end{array}$ \\
\hline & Inter Province & Minister & - & - \\
\hline \multirow[t]{2}{*}{$\begin{array}{l}\text { Permenhut No } \\
\text { P.101/ } 2014 \\
\text { (Guidance of } \\
\text { implementation } \\
\text { of UU 23/2014 on } \\
\text { forestry division }\end{array}$} & One district & $\begin{array}{l}\text { Head of District/ } \\
\text { Mayor }\end{array}$ & $\begin{array}{l}\text { Batam, Bintan } \\
\text { and other island }\end{array}$ & $\begin{array}{l}\text { Duriangkang, } \\
\text { Tembesi (Batam) } \\
\text { Jago (Bintan) }\end{array}$ \\
\hline & Inter district & Governor & Bintan & Pulai, Jang \\
\hline \multirow[t]{2}{*}{$\begin{array}{l}\text { Permenhut } \\
\text { No. P.39/ } 2009 \\
\text { (arrangement of } \\
\text { RPDAST) }\end{array}$} & One district & $\begin{array}{l}\text { Head of District/ } \\
\text { Mayor }\end{array}$ & $\begin{array}{l}\text { Batam, Bintan } \\
\text { and other island }\end{array}$ & $\begin{array}{l}\text { Duriangkang, } \\
\text { Tembesi (Batam) } \\
\text { Jago (Bintan) }\end{array}$ \\
\hline & Inter district & Governor & Bintan & Pulai, Jang \\
\hline
\end{tabular}

Source: Analysis of several regulation sources, 2015. 
The authority of watershed management in Batam Island would be more difficult if it was linked with the Presidential Decree No. 41 of 1973 and the Decree of the Ministry of Home Affairs No. 43 of 1977 and strengthened by the Government Regulation No 46 of 2007 on the rights of land management in Batam Island where the Management Board (BP) of Batam was given the authority to manage land in Batam island. Based on the Ministry of Home Affairs Decree No. 43 of 1977, the rights of land and water management in Batam Island were fully under BP Batam, as stated in Article 4 of the Regulation No. 46 of 2007. If the watershed management used the analogy of land (soil) and water management, the authority of watershed management in Batam Island was under the responsibility of Management Board (BP) Batam, as it also was emphasized in other regulations such as UUPA No. 5 of 1960, Law No. 32 of 2004, Law No. 41 of 1999, Government regulation No. 37 of 2012 and Law No. 37 of 2014, where watershed management and natural resources (forests, soil and water) sustainability became mandatory for stakeholders and beneficiaries of those resources. Therefore, in order to ensure that the watershed management in Batam Island can be more focused, in accordance with the existing regulations, the watershed management in Batam Island should become the authority of BP Batam, at least in the aspects of planning and implementation; while, the evaluation aspects could be carried out by the Central Government via Provincial Government or the Mayor.

\section{Analysis of Stakeholders Related to Institutional of Watershed Management}

\section{Stakeholders}

In accordance with Government Regulation (PP) No. 37 of 2012, the watershed management involved all stakeholders with the principles of integrity, equality and commitment to apply natural resource management in fair, effective, efficient in sustainable ways. The stakeholders related to the watershed management in Batam Island were grouped into four, namely government, private, community and supporting party, as presented in Table 3.

Most of the stakeholders related to the watershed management, especially related to land and water utilization in Batam Island were relatively similar with the stakeholders existed in other watersheds, among others stakeholders related to Garang watershed management in Central Java (Fatahillah, 2013), except the existence of BP Batam and ATB, where the Board was not located in the district/city or other watersheds. Based on the Decree of Ministry of Home Affairs No. 43 of 1977, BP Batam was given the rights as the manager and user in Batam Island. According to that regulation, BP Batam had the authority to 1) plan the allocation and uses of land and water and 2) use land for its requirements. If there were other institutions requiring the land, they must be approved by BP Batam as the holder of rights of land management. In contrast to the existing land in watershed or other islands, the authority of land and water were under the land owner in accordance with the certificate that he or she owned.

Beside BP Batam, in private sector there was Adhya Tirta Batam (ATB), which was in charge of drinking water distribution of Batam city. ATB only utilized the existing surface water, while the water sustainability was the duty of the government or BP Batam. Based on the result of interviews with ATB, the information was obtained that the availability of surface water had decreased. 
Table 3. Distribution of stakeholders related to watershed management in Batam Island

\begin{tabular}{|c|c|c|c|c|}
\hline \multirow{2}{*}{ No. } & \multicolumn{4}{|c|}{ Related Stakeholders } \\
\hline & Government & Private & Community & Upporting \\
\hline 1. & Mayor of Batam & ATB (PDAM Batam) & Farmer Group & NGO \\
\hline 2. & $\begin{array}{l}\text { BP (Management Board) } \\
\text { Batam }\end{array}$ & Companies (CSR) & Community & $\begin{array}{l}\text { Watershed } \\
\text { Forum }\end{array}$ \\
\hline 3. & Provincial Forest Service & & & Academics \\
\hline 4. & Dinas KP2K & & & \\
\hline 5. & City Public Work Service & & & \\
\hline 6. & $\begin{array}{l}\text { Provincial Public Work } \\
\text { Service }\end{array}$ & & & \\
\hline 7. & BWS/PSDA & & & \\
\hline 8. & $\begin{array}{l}\text { Bapedalda (Local } \\
\text { Environmental Impact } \\
\text { Controlling Agency } \\
\text { Bappeda (Local Planning } \\
\text { and Development } \\
\text { Agency) of Batam city }\end{array}$ & & & \\
\hline 10 & $\begin{array}{l}\text { Bappeda Kepri (Local } \\
\text { Planning \& Development } \\
\text { of Riau Islands) }\end{array}$ & & & \\
\hline 11 & $\begin{array}{l}\text { BPDAS (Institute of } \\
\text { Watershed) }\end{array}$ & & & \\
\hline 12 & $\begin{array}{l}\text { BPN (National Land } \\
\text { Agency) }\end{array}$ & & & \\
\hline
\end{tabular}

\section{Perception of Stakeholders}

The results of research on the stakeholders' perception on some of the institutional aspects of the current watershed management were presented in Table 4.

Table 4 showed that the perception and stakeholder's coordination in the institutional aspect of watershed management currently did not yet run well. The stakeholders' activities had not worked in synergy with each other, especially in watershed unit concept. However, all stakeholders agreed that the watershed conditions in Batam Island declined significantly, especially on the sustainability of clean water resources. In order to restore watershed functions, all parties agreed that they all had the responsibility as land users. The results of discussion showed that the Integrated
Watershed Management Plan (RPDAST) had not been used by the stakeholders to participate in watershed management. Activities conducted by the stakeholders, such as Forestry Service and other stakeholders referred to the distribution of maps of critical areas and did not concentrate in watershed unit concept. Similar condition was also found by Ikwanuddin (2010) who mentioned that the damaged watersheds and decrease of carrying capacity of water resources in Java were due to still fragmented watershed handling, either at planning level or at implementation level. Therefore, in order to ensure that the plan of watershed management in Batam Island can run properly, its implementation must be integrated in one watershed concept and in one authority of institution. 
Table 4. Perceptions of Stakeholders on the Institutional Aspect of Watersheds Management in Batam Island

\begin{tabular}{|c|c|c|}
\hline No & Institutional Aspects & Perceptions \\
\hline 1. & Condition of watershed & $\begin{array}{l}90 \% \text { of the parties (respondents) said that the condition } \\
\text { worsened; the availability of clean water (drought) was more } \\
\text { difficult. The surface runoff and erosion was increasing. The } \\
\text { air was getting hotter because of shortage of forest trees. There } \\
\text { were many existing spatial regulations which were not obeyed. } \\
\text { There were wild farmers in some protected areas. }\end{array}$ \\
\hline 2. & Coordination between the parties & $\begin{array}{l}\text { Very weak, there was no reference of implementation in the } \\
\text { management, except on the critical areas. Each party walked } \\
\text { on their own. }\end{array}$ \\
\hline 3. & Reference of activities & $\begin{array}{l}\text { Walk alone, integrated watershed management plan not yet } \\
\text { followed }\end{array}$ \\
\hline 4. & Resource & $\begin{array}{l}\text { Most of them said that it was the duty of the government (APBN } \\
\text { / APBD), Smaller part said from land utilization/private. }\end{array}$ \\
\hline
\end{tabular}

Source: Primary data of discussion results, 2015.

\section{Interest and Power of the Stakeholders}

Crosby (1992) in Iqbal (2007) said that in institutional analysis, there were two things that need to be studied, namely interest and strength or power from related stakeholders. Interests and power of stakeholders became the deciding factors whether or not an institution acted in an activity. In this study, the interest of stakeholders were seen on tasks and functions carried out by the stakeholders and their activities, while the power was seen from how much the stakeholders were to consolidate or control other stakeholders in watershed management implementation. The research results showed that level of interest and power of parties in Batam Island were scattered in three quadrants namely quadrant 1, quadrant 2 and quadrant 4 (Figure 3).

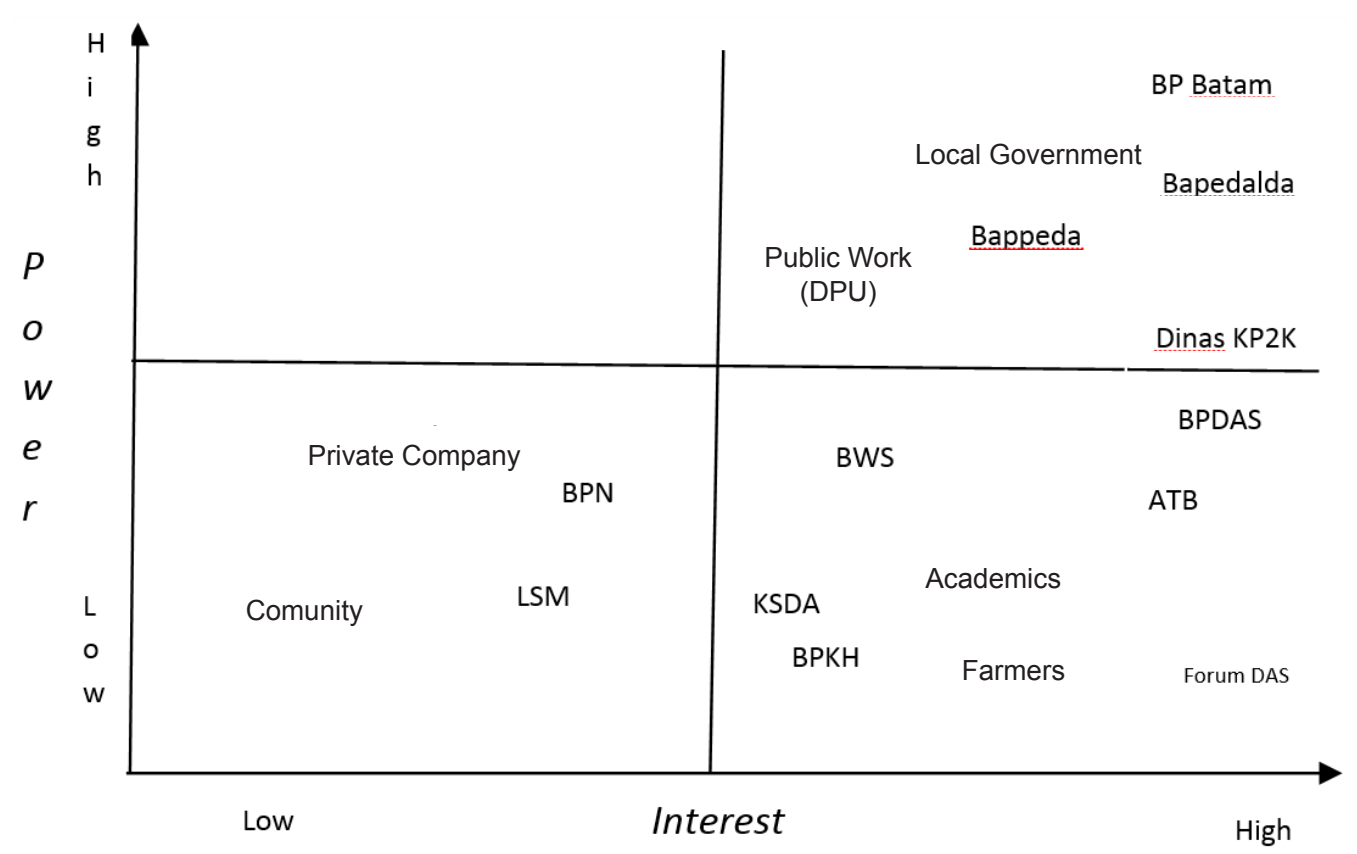

Figure 3. The level of interest and Power of Stakeholders on Watershed Management in Batam Island.

From Figure 3, Quadrant 1 was the stakeholders who had low interest and low power. Those included in this group were ordinary people, private (companies), and 
NGOs except NGOs related to environment and BPN (National Land Agency). Quadrant 2 was a group having high interest but low power in controlling other groups. Those included in this group were Central UPT (Technical Executing Unit) including BPDAS (Institute of Watershed management), DAS Forum (Watershed Forum), academics and ATB. Quadrant 4 was a group having high interest and power in controlling other groups. This group was expected to drive the sustainability of watershed management because in addition to having high interest, they also had the ability to control groups or other stakeholders. Those included in this group were the Mayor, Bappeda (Local Planning Board), BAPEDALDA (Local Environment Impact Controlling Board), Agriculture and Forestry Service, Provincial Public Works Service and BP (Management Board) Batam.

From several institutions existed in quadrant four, all FGD participants agreed that BP Batam had the highest power since Otorita Batam (Batam Authority) had full authority over land use in Batam Island, including the availability of communities' water needs, while Mayor including his officials were more on the community administration. Therefore, in accordance with the power level of BP Batam in land use and its level of interest in sustainability of watershed and water resources, BP Batam was needed to be given the authority in watershed management. It could even become the key position to the achievement of better watershed management in Batam Island.

\section{Institutional Model of Watershed Management in the Future}

An effective institutional management was an institutional management which was able to reflect linkages of biophysical environment with socio-economic conditions where the institution operated (Asdak, 2010). Besides, the existing institutional management must have the ability and power to control both biophysical and communities existed in a region. Based on the above research results, an institutional model of watershed management possibly to be recommended for watersheds in Batam Island was an institutional model associated with authority granting Batam Island Area management, in this case towards Batam Authority Area.

In accordance with the Decree of Ministry of Home Affairs No. 43 of 1977, Management Board or Otorita Batam was given the authority to manage Batam Island and several surrounding islands to be developed to become economic zone. Based on that regulation, the Management Board had full authority to use the land in Batam Island. In accordance with the findings on a research conducted by Anggraeni et al., (2014) that legally BP Batam was authorized as the rights holder of Batam city administrator. If it was associated with the Basic Agrarian Law (UUPA) of 1960, Article 15 stated that every person, legal entity, or industry that had a legal authority with the land is required to maintain the land, including adding fertility and preventing damage. Therefore, to also refer to the Regulation No. 37 of 2014 on Soil and Water Conservation, Article 30 paragraph (1-2) stated that every person who used land and water on any land (protected, cultivation) was obliged to carry out Soil and Water Conservation. Therefore, the watershed management in Batam Island should be done and become the duty of Management Board (BP) Batam.

To apply this model, organizationally Batam Management Board needed to be strengthened by its organizational structure. The research results showed that for the time being, the programs and activities related to handling of the environment (watershed management) were still at sub-division level, which was better of course to be increased at least becoming a division. Similarly, the budget and available human resources needed to be added. Besides, in addition to the tasks listed in the Decree of the Minister of Home Affairs No. 43 of 1977, it was also to be added some 
tasks related to environmental management, including watershed management, which referred to norms, standards, procedures and management indicators made by Central Government (Law No. 23 of 2014).

Remembering that institutional changes and implementation was not easy and will generate some implications so in its application can be done through two models:

1. Full Watershed Institutional Management of Otorita Batam

In this model, watershed management obligations were fully implemented by the Management Board of Batam as legal consequences of the existing regulations. The Integrated Watershed Management Plan which was originally signed by the Mayor, now signed by BP Batam as part of Batam Island management plan. The watershed management plan became an integral part of Batam Island development plan, starting from planning, implementation and evaluation of implementation. In this model, the central government set the criteria and indicators of land and water utilization specifically or watershed management in general. From those criteria and indicators, BP Batam ran their obligations to manage watershed in Batam Island. The weakness of this approach was the readiness level of Management Board in taking over the important role and functions which was previously carried out by various stakeholders. In addition, these changes would raise some "sacrifices" made by other agencies that had previously participated in organizing the watershed management. The advantage was that the Management Board would have full authority to manage watershed in accordance with the criteria and indicators that had been set up by legislation.

2. Institutional Watershed Management Involving Relevant Agencies.

In this model, the watershed management obligation was fully executed by the Management Board of Batam as legal consequences of the existing regulations. At present, the Management Board remains fully responsible for managing watershed in accordance with the criteria and indicators that have been set up by legislation. The difference was that the relevant agencies were still involved; they were among others BPDAS (Institute of Management of Watershed) as planning and evaluation, technical offices as executors of the watershed management plans, Watershed Forum, NGOs, and Universities, including Provincial Government.

\section{Conclusions and Recommendations}

1. The Institutional management of Batam watershed had not run properly. In addition, the coordination was still weak, each party ran on their own advances, and the board had not yet used DAS (watershed) as a reference activity.

2. The rules and regulations related to watershed management institutions in Batam Island were still overlapping. On one side, BP Batam was given the authority to manage and to utilize land and water; however, on the other side, an integrated watershed management plan was signed by the Mayor of Batam. Therefore, the plan was difficult to be implemented.

3. The stakeholders related to watershed institutional management in Batam Island were largely similar to other regions, except on the existence of Batam Authority (Otorita Batam), which was appointed by the government to develop Batam Island to become Strategic Industrial Zone.

4. The levels of interest and power of stakeholders in watershed institutional management were distributed across three quadrants, namely quadrant 1 (weak), quadrant 2 (rather weak), and quadrant 4 (strong). The stakeholders in quadrant 4 included Mayor, Bappeda (Local Planning Development), BAPEDALDA (Local Environmental Impact Controlling 
Agency), Provincial Public Works 5. From the above results of studies, it was Service, Department of P2KP, and BP (Management Board) Batam. Of all the stakeholders, BP Batam (Management Board of Batam) had the power and the key role in determining the success of watershed management in Batam Island. suggested that BP Batam should be given the authority in watershed management in Batam Island, either in terms of planning aspects or implementing aspects that still referred to the norms, standards, procedures and indicators set by the central government.

\section{References}

Anggraeni, I., Muhammad Bakri dan Jazin Hamidi, 2014. Akibat Hukum Inskronisasi Pengaturan Bidang Pertanahan di Kota Batam. Jurnal Hukum 2014 Universitas Brawijaya Malang. https://hukum.studentjournal.ub.ac.id.

Anna, Alif Noor, Retno Woro Kaeksi, dan Wahyuni Apri Astuti, (2010). Analisis Karakteristik Parameter Hidrologi Akibat Alih Fungsi Lahan Di Daerah Sukoharjo Melalui Citra Lansat Tahun 1997 Dengan Tahun 2002. Forum Geografi Vol 24 No 1, July 2010, p 57-72.

Asdak, Chay., 2010. Hidrologi dan Pengelolaan Daerah Aliran Sungai Gadjah Mada University Press. Yogyakarta.

BP. Batam, 2015. Data Geogafis Pulau Batam (www.bpbatam.go.id).

Batam Indonesia, 2015. Batam Indonesia Free Zone Authority. Edition I Volume XXVII Year 2015.

BPKH, 2015. Peta Kawasan Hutan Pulau Batam Tahun 2015. Balai Penataan Kawasan Hutan Propinsi Kepulauan Riau, Tanjungpinang.

BPTPDAS, 2014. Perencanaan dan Kelembagaan Pengelolaan Daerah Aliran Sungai di Pulau Batam. Balai Penelitian Teknologi Pengelolaan Daerah Aliran Sungai, Surakarta. Laporan Proyek [Project Report].

BPDAS Kepri, 2011. Rencana Pengelolaan DAS Terpadu Duri Angkang. Buku I. Kerja sama BPDAS Kepri, Pemerintahan Kota Batam dan BP Batam.

BPS, 2013bit. Kepulauan Riau Dalam Angka Tahun 2013. Badan Pusat Statistik Kepulauan Riau.

BPTPDAS, 2014. Karakteristik Pulau-pulau Kecil di Kepulauan Riau (Laporan Pelaksanaan Penelitian Tahun 2014 [Research Report of 2014]).

Cahyadi, A., Marfai, M.A., Tivianto, T.A., Wulandri, Wahyu, H. 2013. Analisis distribusi spasial salinitas air tanah di pulau Pramuka, Kepulauan Seribu, DKI Jakarta. Prosiding Seminar Pendayagunnaan Informasi Geografis untuk Optimalisasi Otonomi Daerah.

Fatahillah, M., 2013. Kajian Keterpaduan Lembaga Dalam Pengelolaan DAS Garang, Propinsi Jawatengah. Tesis S2 Program Magister Ilmu Lingkungan, Program Pasca Sarjana, Universitas Dipenegoro, Semarang

Ikwanuddin, Mawardi, 2010. Kerusakan DAS dan Penurunan Daya Dukung Sumberdaya Air di Pulau Jawa dan Upaya Penanganannya. Jurnal Hidrosfir Indonesia Vol 5 No 2 Year 2010.

Iqbal, M. Dan Sumaryanto, 2007. Strategi Pengendalian Alih Fungsi Lahan Pertanian Bertumpu pada Partisipasi Masyarakat. Analisis Kebijakan Pertanian, Volume 5 No 2, June 2007. Pusat Analisis Sosial Ekonomi dan Kebijakan Pertanian. Bogor. 
Johnson, DP., 1999. Teori Sosiologi Klasik dan Moderen. PT. Gramedia Jakarta.

Keppres No 12 Tahun 2012 tentang Penetapan Wilayah Sungai.

Kemenhut No. SK. 328/Menhut-II/2009 tentang Penetapan Daerah Aliran (DAS) Sungai Prioritas.

Kemendagri No 43 Tahun 1977 tentang Pengelolaan dan Penggunaan Tanah di Daerah Industri Pulau Batam.

Keppres No 41 Tahun 1973 tentang Daerah Industri Pulau Batam.

Medrial Zain A., Mukaryanti dan Diar Siddiq. 2006. Evaluasi Kemampuan Alami Wilayah Dalam Konservasi Air dan Pengendalian Banjir. Jurnal Teknologi Lingkungan P3TLBPPT 7 (1): 26-34.

Mitchell, G. Duncan (ed). 1968. A Dictionary of Sociology. Routledge and Kegan Paul, London.

Permenhut No. P. 39/Menhut-II/2009 tentang Pedoman Penyusunan Rencana Pengelolaan Daerah Aliran Sungai Terpadu.

Permenhut No. P 101/Menhut-II/2014 tentang Pedoman Pelaksanaan Pelimpahan Sebagian Urusan Pemerintahan (Dekonsentrasi) Bidang Kehutanan Tahun 2015 yang dilimpahkan kepada Gubernur selaku wakil pemerintah.

PP. 37 Tahun 2012 tentang Pengelolaan Daerah Aliran Sungai. Lembaran Negara Republik Indonesia Tahun 2012 Nomor 62.

PP No 87 Tahun 2011 tentang Rencana Tata Ruang Kawasan Batam, Bintan, dan Karimun. Lembaran Negara Republik Indonesia Tahun 2011 No 127.

PP No 46 Tahun 2007 tentang Kawasan Perdagangan Bebas dan Pelabuhan Bebas Batam. Lembaran Negara Republik Indonesia Tahun 2007 No 4757.

Pramono, IB., Syahrul Donie, Tyas M. Basuki, Rahardyan A. Nugroho, S. Andy Cahyono, Wahyu Wisnu Wijaya, Sudarso dan Ragil B.W.P. ( 2015). Sistem Perencanaan dan Kelembagaan DAS Pulau Batam dan Karakteristik DAS Pulau Bintan. Balai Penelitian Teknologi Kehutanan Pengelolaan Daerah Aliran Sungai, Surakarta. Laporan Proyek 2015.

Sianipar, R.B., 2011. Batam terancam krisis air bersih 2015. www.republika.co.id. Downloaded on 16 March 2011.

Trimeko, RW., 2014. Ketahanan Air Untuk Indonesia : Pandangan Akademisi. Seminar Water Security for Indonesia Examining the Water-Energy-Food Nexus. Indonesia Water Learning Week (IWLW). Universitas Katolik Parahiyangan, Bandung.

Utaya, Sugeng, 2008. Pengaruh Perubahan Penggunaan Lahan Terhadap Perubahan Sifat Biofisik Tanah dan Kapasitas Infiltrasi di Kota Malang. Jurnal Forum Geografi Vol 22 No 2, December 2008. p 95-112.

UUPA No 5 Tahun 1960 tentang Peraturan Dasar Pokok-pokok Agrari Lembaran Negara Republik Indonesia Tahun 1960 No 2043.

UU No 32 Tahun 2004 tentang Pemerintahan Daerah. Lembaran Negara Republik Indonesia Tahun 2004 No 4437.

UU No 41 Tahun 1999 tentang Kehutanan. Lembaran Negara Republik Indonesia Tahun 1999 No 167. 
UU No 23 tahun 2014 tentang Pemerintahan Daerah. Lembaran Negara Republik Indonesia Tahun 2014 No 244.

UU No 37 Tahun 2014 tentang Konservasi Tanah dan Air. Lembaran Negara Republik Indonesia Tahun 2014 No 299.

UU No.27 Tahun 2007 tentang Pengelolaan Wilayah Pesisir dan Pulau-pulau Kecil. Lembaran Negara Republik Indonesia Tahun 2007 No 84.

Uphoff, Norman, 1986. Local Institution Development: An Analytical Sourcebook With Cases. Kumarian Press. 